\title{
Isolation and characterization of Botryococcus braunii from a freshwater environment in Tenggarong, Kutai Kartanegara, Indonesia
}

\author{
RUDY AGUNG NUGROHO ${ }^{1, \boldsymbol{\vartheta}}$, DIRGARINI JULIA NURLIANTI SUBAGYONO ${ }^{2}$, ENOS TANGKE ARUNG ${ }^{3}$ \\ ${ }^{1}$ Department of Biology, Faculty of Mathematics and Natural Sciences, Universitas Mulawarman. Jl. Barong Tongkok No. 4, Gunung Kelua, Samarinda \\ 75123, East Kalimantan, Indonesia. Tel./fax.: +62-541-756123, `email: rudyagung.nugroho@ fmipa.unmul.ac.id \\ ${ }^{2}$ Department of Chemistry, Faculty of Mathematics and Natural Sciences, Universitas Mulawarman. J1. Barong Tongkok No. 4, Gunung Kelua, \\ Samarinda 75123, East Kalimantan, Indonesia \\ ${ }^{3}$ Faculty of Forestry, Universitas Mulawarman. Jl. Ki Hajar Dewantara, Gunung Kelua, Samarinda 75123, East Kalimantan, Indonesia
}

Manuscript received: 30 March 2020. Revision accepted: 30 April 2020.

\begin{abstract}
Nugroho RA, Subagyono DJN, Arung ET. 2020. Isolation and characterization of Botryococcus braunii from a freshwater environment in Tenggarong, Kutai Kartanegara, Indonesia. Biodiversitas 21: 2331-2336. The use of microalgae as an alternative source of oil has gained much attention in recent years. The present study was conducted to isolate and characterize microalgae Botryococcus braunii from a freshwater environment, located in Tenggarong, Kutai Kartanegara, East Kalimantan, Indonesia. B. braunii were cultured and determined their growth in terms of biomass yield and the presence of lipid globules by red Nile staining. Dry biomass, phosphate, and protein content of cultured B. braunii were measured at 3 days of intervals for 24 days. Biomass yield, hydrocarbon, carotenoid, and chlorophyll content were determined at the $\mathrm{pH}$ range of $6,6.5,7,7.5$, and 8 and various $\mathrm{CO}_{2}$ concentrations. The result showed that $B$. braunii collected from freshwater in Tenggarong can produce lipid globules. The highest growth of $B$. braunii was reached at day 15 , while the optimal phosphate content was on the $12^{\text {th }}$ day, and the protein was relatively stable during culture. The optimal weight of $B$. braunii biomass was reached at $\mathrm{pH} 7$ and $4 \% \mathrm{CO}_{2}$ and the highest hydrocarbon content was obtained at $\mathrm{pH} 8$ and $4 \% \mathrm{CO}_{2}$. The highest chlorophyll and carotenoid contents were obtained $4 \% \mathrm{CO}_{2}$. In conclusion, B. braunii collected from Tenggarong was successfully cultured and able to produce lipid globules. The optimal conditions for its growth and production of hydrocarbon, phosphate, protein, chlorophyll, and carotenoid were at $\mathrm{pH}$ of $7-8$ and $4 \% \mathrm{CO}_{2}$.
\end{abstract}

Keywords: Botryococcus braunii, growth, hydrocarbon, lipid droplets

\section{INTRODUCTION}

The need for renewable energy resources, particularly biofuel, has become a significant concern in the last few decades. This demand has been primarily driven by population growth and industrialization, both of which depend on fossil fuels (Medipally et al. 2015; Shuba and Kifle 2018). However, fossil-based fuel sources are continually declining, so it becomes a big problem for most countries (Mercure et al. 2018). As an alternative energy source, the biomass of organisms such as microalgae, namely Botryococcus braunii is a potential renewable source for biofuel (Chaudry et al. 2018; Sadeghin et al. 2018; Tsutsumi et al. 2018).

Botryococcus braunii is a microalga with a pyriform shape and is green plankton, with a cell size of $80-139 \mathrm{~mm}$. It can be found in freshwater environments, brackish lakes, reservoirs, and ponds (Tasić et al. 2016). It can produce lipids up to $65 \%$, contain high amounts of hydrocarbons and other types of lipids (Banerjee et al. 2002; Metzger and Largeau 2005; Tasić et al. 2016). High lipid producing microalgae has the potential to substitute fossil-based energy sources by processing their biomass into biofuels (Nurhatika et al. 2018). Lipid content in microalgae can be detected using a simple and rapid method of Nile red dye staining. Nile red contains a dye that fluoresces mainly in non-polar environments, lipophilic and emits intense fluorescence in hydrophobic organic solvents. Nile red stain can contact lipid bodies, therefore it has the potential for lipid staining and quantification (Kimura et al. 2004; Huang et al. 2009; Bertozzini et al. 2011; Storms et al. 2014).

The growth and production of lipids in B. braunii are affected by several factors, such as nutrition, temperature, salinity, $\mathrm{pH}, \mathrm{CO}_{2}, \mathrm{DO}$ and turbidity (Al-Hothaly et al. 2016; Jin et al. 2016; Concha et al. 2018; Cheng et al. 2019). Optimum growth conditions result in producing a high amount of biomass, hydrocarbons, chlorophyll, phosphates, proteins carotenoids (Cepák and Přibyl 2018; Uchida et al. 2018; Wan et al. 2019). Previous research has determined that $2 \%(\mathrm{v} / \mathrm{v}) \mathrm{CO}_{2}$ increased the growth performance of B. braunii (Ruangsomboon et al. 2017), enhanced chlorophyll content (Uquiche et al. 2016), produced more hydrocarbon and led to a two-fold increase of carotenoid content (Ranga Rao et al. 2007). According to Jin et al. (2016), pH is an important factor for biomass and hydrocarbon production in $B$. braunii cultures. The optimal $\mathrm{pH}$ for hydrocarbons production in $B$. braunii is 6.5 while $\mathrm{pH} 6.0$ affected biomass production.

Our preliminary observation conducted by author also showed that the freshwater environment in Tenggarong, Kutai Kartanegara, East Kalimantan supported the growth of $B$. braunii. However, the isolation and characterization of $B$. braunii have not been done yet. The present research aimed to isolate and characterize the growth of $B$. braunii 
from the freshwater environment at Tenggarong, Kutai Kartanegara, East Kalimantan, Indonesia.

\section{MATERIALS AND METHODS}

\section{Sampling site of Botryococcus braunii sampling}

Microalga was collected and isolated from the freshwater environment in Tenggarong, Kutai Kartanegara District, East Kalimantan Province, Indonesia ( $0^{\circ} 25^{\prime} 38.35^{\prime \prime}$ S; $117^{\circ} 00^{\prime} 23.21^{\prime \prime}$ E) (Figure 1). Samples were collected using a $100 \mu \mathrm{m}$ mesh size plankton net. Individual colonies of Botryococcus braunii from the freshwater sample were subjected to purification by serial dilution. B. braunii OIT 413 strain from the Osaka Institute of Technology, Osaka, Japan was used as a reference. Individual colonies of $B$. braunii collected from freshwater in Tenggarong were isolated and inoculated into AF 6 liquid medium (Watanabe et al. 2000; Watanabe 2005). B. braunii inoculum was incubated under 12-hrs light: $12 \mathrm{hrs}$ dark conditions (12L: 12D) photoperiod and $1.2 \pm 0.2 \mathrm{klux}$ light intensity at $25-27^{\circ} \mathrm{C}$. Pure colonies/culture of $B$. braunii were obtained from repeated inoculation and regularly observed under the light microscope.

\section{Morphological profile and Nile red assay}

The obtained colonies of $B$. braunii wild type were observed for their morphological profile using a light microscope (Primo Star, Carl Zeiss Microscopy GmbH, Germany). The potential oil production of $B$. braunii was detected by a simple staining method (Nile red). Nile red dye (9-(diethylamino) benzo[a]phenoxazin-5(5H)-one) was obtained from Sigma-Aldrich Pty. Ltd. (Singapore). A few drops of $B$. braunii pure culture were added to a drop of Nile red solution. The mixture was allowed to stand for one minute at room temperature. The development of fluorescence of the stained mixture was observed using a fluorescence microscope (Nikon Corporation, Japan).

\section{Growth of Botryococcus braunii}

Botryococcus braunii collected from freshwater was cultured in $150 \mathrm{~mL}$ Erlenmeyer flasks in triplicate. Forty $\mathrm{mL}$ of AF 6 medium was inoculated with B. braunii at 20\% $(\mathrm{v} / \mathrm{v})$, then incubated with 12L: 12D photoperiod and light intensity of $1.2 \pm 0.2 \mathrm{klux}$ at $25-27^{\circ} \mathrm{C}$. Cultures were harvested at 3 days of intervals for 24 days, and dry biomass was calculated until day 24th. The dry biomass weight was determined as follows: the harvested of $B$. braunii culture was centrifuged at $5000 \mathrm{rpm}$, and then pellets were washed using distilled water and freeze-dried. The dried pellets were weighed and evaluated gravimetrically. The growth of $B$ braunii was expressed in terms of dry weight. Besides dry biomass, phosphate and protein content were also determined.

\section{Estimation of phosphate and protein content}

Phosphate content in the harvested B. braunii culture was measured as follows: The harvested $B$. braunii was centrifuge (Beckman Allegra X-22R, Beckman Coulter, USA) at a speed of $8000 \mathrm{rpm}$. The supernatant was collected, and the phosphate content was analyzed using Fiske-Subbarao's method (Fiske and Subbarow 1925). B. braunii protein content was determined with a Protein Assay Kit (Invitrogen, Q33211 from Thermo Fisher Scientific) and detected using a Qubit ${ }^{\mathrm{TM}} 4$ fluorometer (Thermo Fisher Scientific, USA).
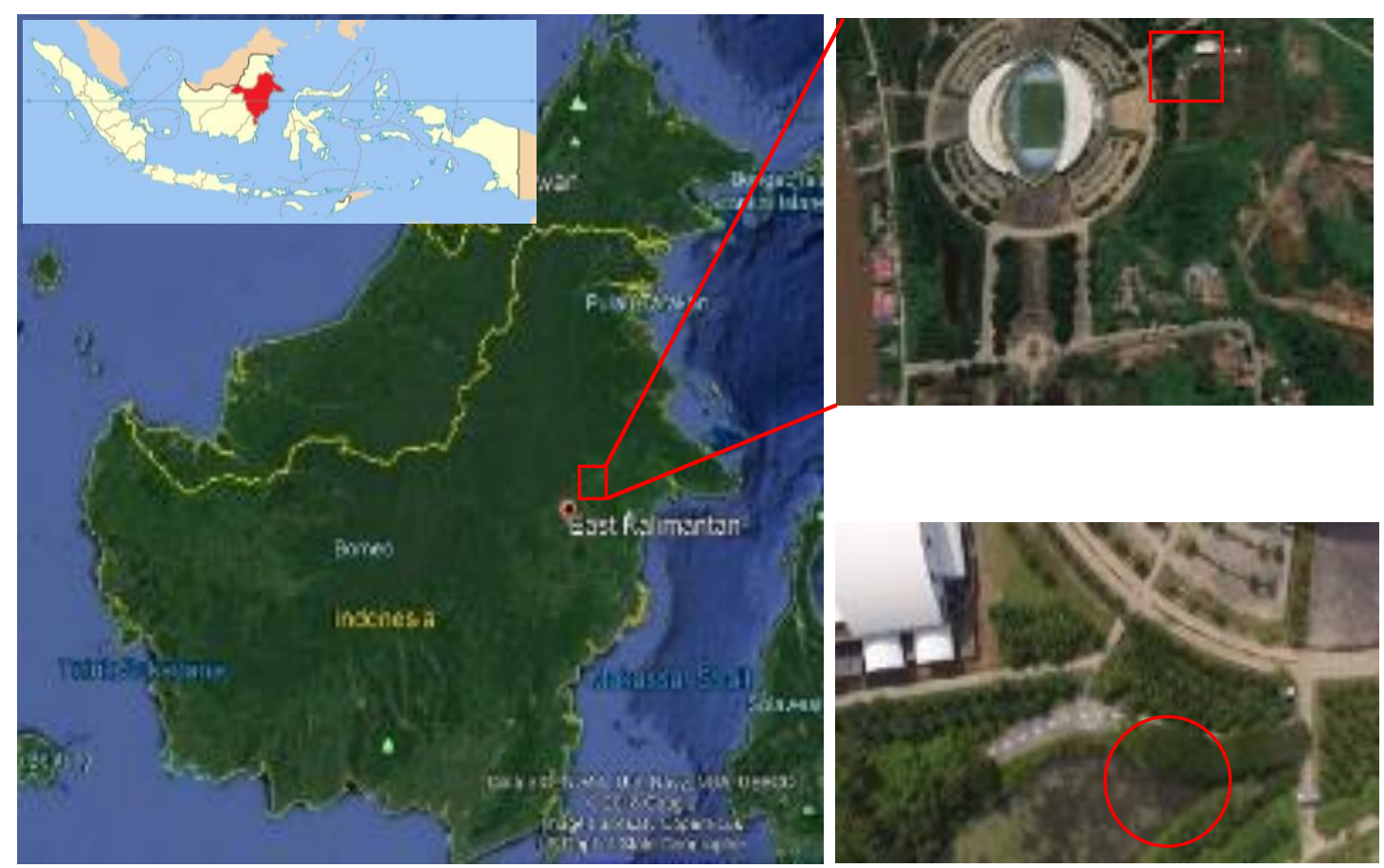

Figure 1. Sampling site $\left(0^{\circ} 25^{\prime} 38.35^{\prime \prime} \mathrm{S} ; 1^{\circ} 7^{\circ} 00^{\prime} 23.21^{\prime \prime} \mathrm{E}\right)$ of wild type Botryococcus braunii from the freshwater environment, Tenggarong, Kutai Kartanegara, East Kalimantan, Indonesia 
The effect of pH on biomass and hydrocarbon content

The biomass and hydrocarbon content of $B$. braunii cultures were measured at the $\mathrm{pH}$ range of $6,6.5,7,7.5$, and 8 . Forty $\mathrm{mL}$ of AF6 medium in the Erlenmeyer flask $(150 \mathrm{~mL})$ and the $\mathrm{pH}$ of culture medium was adjusted before sterilization. B. braunii was inoculated at $25 \%(\mathrm{v} / \mathrm{v})$ and incubated for three weeks under a $12 \mathrm{~L}$ : $12 \mathrm{D}$ photoperiod, $1.2 \pm 0.2$ klux light intensity, and $26-28^{\circ} \mathrm{C}$. After three weeks, the culture was harvested, and biomass and hydrocarbon content were analyzed

\section{The effect of carbon dioxide on biomass weight,} hydrocarbon, chlorophyll-a, and carotenoid content

Two-tier Erlenmeyer flasks were used for photoautotrophic growth experiments. Two-week-old $B$. braunii culture was inoculated at $25 \%(\mathrm{v} / \mathrm{v})$ in the upper chamber, while the lower chamber was filled with $100 \mathrm{~mL}$ of carbonate $(3 \mathrm{M})$ and bicarbonate $(3 \mathrm{M})$ mixture solutions. To obtain $0.5,1.0,2$, and $4 \%(\mathrm{v} / \mathrm{v})$ partial pressures of $\mathrm{CO}_{2}$, the mixture of carbonate $(3 \mathrm{M})$ and bicarbonate $(3 \mathrm{M})$ solutions were established as per Tripathi et al. (2001). The Erlenmeyer flask was tightly sealed using a cotton plug and aluminum foil. The culture was incubated for three weeks under 12L: 12D photoperiods, $1.2 \pm 0.2$ klux light intensity, and $26-28{ }^{\circ} \mathrm{C}$. The assays were performed in triplicate. At the end of the incubation period, the culture was harvested, and biomass, hydrocarbon, carotenoid, and chlorophyll yields were measured.

\section{Chlorophyll content}

Chlorophyll content was determined spectrophotometrically using a Jenway 6305 UV/VIS spectrophotometer at $750 \mathrm{~nm}, 664 \mathrm{~nm}, 647 \mathrm{~nm}$, and $630 \mathrm{~nm}$. Before analysis, the $B$. braunii culture was extracted using a centrifuge at $4000 \mathrm{rpm}$ for $10 \mathrm{~min}$. To obtain a turbidity-corrected value, the absorbance at $750 \mathrm{~nm}$ was subtracted from three different wavelengths, with $90 \%$ acetone being used as a blank. Chlorophyll a content was calculated following the equation provided by Johan et al. (2014).

Chl-a $(\mu \mathrm{g} / \mathrm{L})=\left(11.85 \times \mathrm{E}_{664}\right)-\left(1.54 \times \mathrm{E}_{647}\right)-\left(0.08 \times \mathrm{E}_{630}\right)(1)$

Concentration of Chl-a (mg/L) $=[$ Chl-a X v $] / \mathrm{V} \times \mathrm{L}$ (2)

Where:

$\mathrm{v} \quad$ : Volume of acetone $90 \%(\mathrm{~L})$

$\mathrm{V} \quad$ : Volume of water sample (L)

L : Lightpath of cuvette $(\mathrm{cm})$

$\mathrm{E}_{664}$ : Value of absorbance at wavelength $664 \mathrm{~nm}$

$\mathrm{E}_{647}$ : Value of absorbance at wavelength $647 \mathrm{~nm}$

$\mathrm{E}_{630}$ : Value of absorbance at wavelength $630 \mathrm{~nm}$

\section{Carotenoid content}

Carotenoid content was determined according to the methods of Lichthentaler (1987). Respectively, a known volume of $B$. braunii culture was centrifuged at $8000 \mathrm{rpm}$ for $10 \mathrm{~min}$. The resulting pellet was added to a known volume of methanol and kept in a water bath at $60^{\circ} \mathrm{C}$ for 30 min to extract the carotenoid, the absorbance of carotenoid was measured at 652 and $665 \mathrm{~nm}$.

\section{Hydrocarbon extraction and analysis}

Dry biomass of $B$. braunii was extracted using hexane. The dry biomass in hexane was centrifuged at $5000 \mathrm{rpm}$ for $10 \mathrm{~min}$ and the recovered supernatant was evaporated to dryness. Hydrocarbon content was measured gravimetrically and expressed as a dry weight percentage (Dayananda et al. 2005, 2006).

\section{RESULTS AND DISCUSSION}

\section{Morphological profile}

Isolation and characterization of potential renewable sources for sustainable energy production are very important to be carried out. For several years, there have been various attempts to find oil-producing microalga. Oil production from microalga is still far from economically feasible for the public market, however, its significant potential needs to be studied and developed. The result of this study showed that $B$. braunii collected from a freshwater environment in Tenggarong, Kutai Kartanegara, East Kalimantan, Indonesia showed the presence of oil lipid globules in B. braunii (Figure 2).

In Figure 2, the Nile red dye reacted with lipid globules, results in emitting either orange or yellow fluorescence, whereas the chlorophyll in B. braunii cells emits red autofluorescence. Nile red staining has been used in several previous studies to monitor lipid globules under different physiological conditions in a number of different microorganisms, such as oleaginous yeasts (Rostron et al. 2015), oleaginous fungus Penicillium citrinum (Bardhan et al. 2019) and various microalgal species belonging to Bacillariophyceae (Natunen et al. 2017) and Chlorophyceae classes (Kamalanathan et al. 2018).
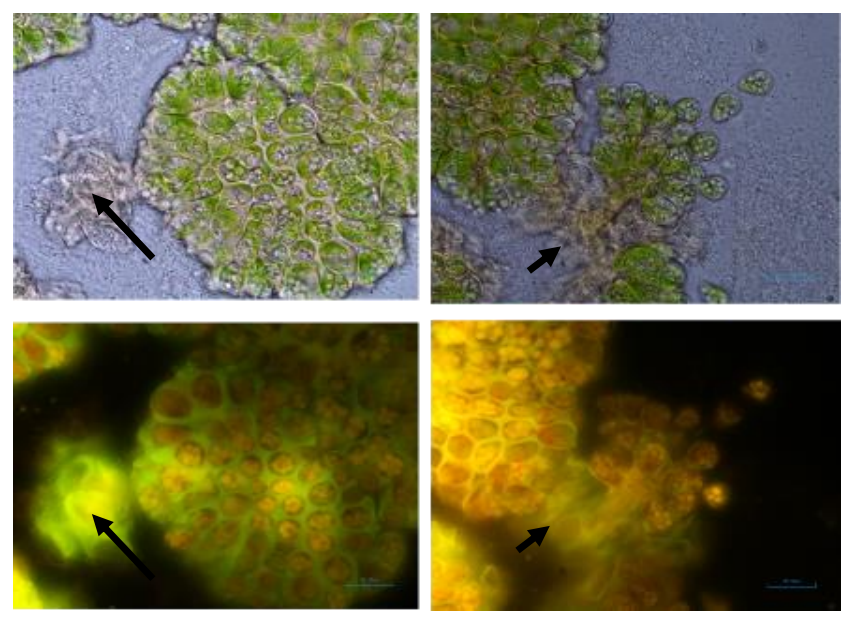

Figure 2. The colony of Botryococcus braunii before (upper) and after (lower) being stained with Nile red dye. Note: $\rightarrow$ : lipid globule 
Nile red staining is a simple and rapid alternative method that has frequently been used to identify or quantify lipid bodies in various organisms, including microalgae. Nile red contains a dye that fluoresces preferentially in non-polar environments and is a lipophilic dye that emits intense fluorescence in hydrophobic organic solvents. This dye can contact lipid bodies, making a natural candidate for lipid staining and quantification (Kimura et al. 2004; Huang et al. 2009; Bertozzini et al. 2011; Storms et al. 2014).

\section{Growth of Botryococcus braunii}

The growth curve of $B$. braunii which was isolated from a freshwater environment in Tenggarong, Kutai Kertanegara, East Kalimantan, Indonesia was presented in Figure 3. A single colony of $B$. braunii was cultured in AF6 medium and sub-cultured every two weeks. Figure 3 showed that the growth of $B$. braunii showed an incremental increase up to day 2 under 12L: 12D photoperiods, $1.2 \pm 0.2$ klux light intensity, and $26-28^{\circ} \mathrm{C}$. Previous research also noted successful isolation of $B$. braunii from several freshwater environments (Szőke-Nagy et al. 2015; Prasertsin and Peerapornpisal 2018; Xu et al. 2018), and the optimal biomass dry weight of B. braunii was on day 15 using BG11 medium at an ambient temperature of $28{ }^{\circ} \mathrm{C}$ with a light intensity of $65 \mu \mathrm{mol}$ $\mathrm{m}^{-2} \mathrm{~s}^{-1}$ (Xu et al. 2018).

Phosphate content in culture media decreased on days 12-15, indicating that phosphate utilization is required for $B$. braunii growth, whereas the level of protein slightly increased after day 15 (Figure 4). This finding is following the previous study that increasing protein content is due to cellular lysis (Casadevall et al. 1985). Phosphate was used at the beginning of the exponential growth of $B$. braunii, followed by an increase in the level of phosphate at the final stages of culture. B. braunii has a lower concentration of phosphorus compared to many other algae on an organic basis (Tsukahara and Sawayama 2005).

\section{Effects of pH on growth and hydrocarbon content}

Botryococcus braunii growth is affected by several factors, such as light, nutrients, $\mathrm{CO}_{2}$, temperature, water, and pH (Ruangsomboon 2012; Onalo et al. 2014; Gani et al. 2015). B. braunii has a specific feature concerning its growth-related hydrocarbon requirements (Kojima and Zhang 1999). The results showed that $\mathrm{pH} 7$ in culture media produced optimal biomass dry weight but lower hydrocarbon content. In contrast, the highest hydrocarbon content was at $\mathrm{pH} 8$ but reduced biomass dry weight (Figure 5). These findings are consistent with the results of Jin et al. (2016) that optimal hydrocarbon content was reached at $\mathrm{pH}$ 6.5, whereas $\mathrm{pH}$ 6.0-8.0 had less effect on the biomass dry weight.

Botryococcus braunii is known as a long-chain hydrocarbon producer. There are several long-chain hydrocarbons produced by $B$. braunii, including $\mathrm{C}_{27}$ diene, $\mathrm{C}_{27}$ triene, $\mathrm{C}_{30}$ botryococcene, squalene, tetramethyl squalene, and trs,trs-lycopadiene (Metzger and Largeau 2005). According to Largeau et al. (1980), B. braunii accumulates hydrocarbon in different locations, mainly in cytoplasmic inclusions (internal) and outer walls or derived globules (external). Besides, hydrocarbons with shorter chains can be found in a higher degree in the internal pool. Almost $95 \%$ of hydrocarbons are also found in the external pool, whereas a normal level of about $0.75 \%$ is located within the cells.

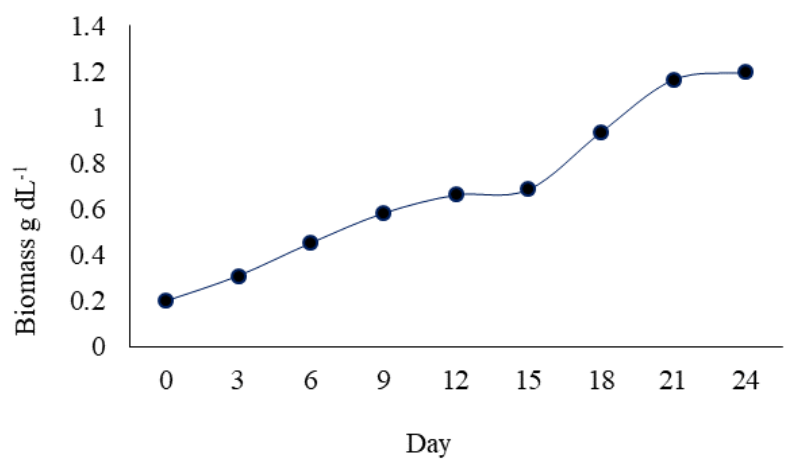

Figure 3. Growth curve of Botryococcus braunii isolated from the freshwater environment in Tenggarong, Kutai Kartanegara, East Kalimantan, Indonesia

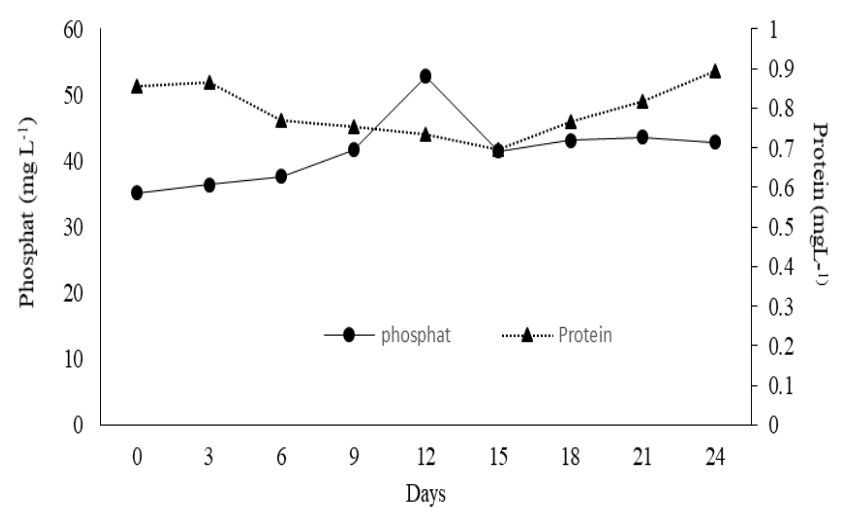

Figure 4. Phosphate concentration and protein content in Botryococcus braunii culture

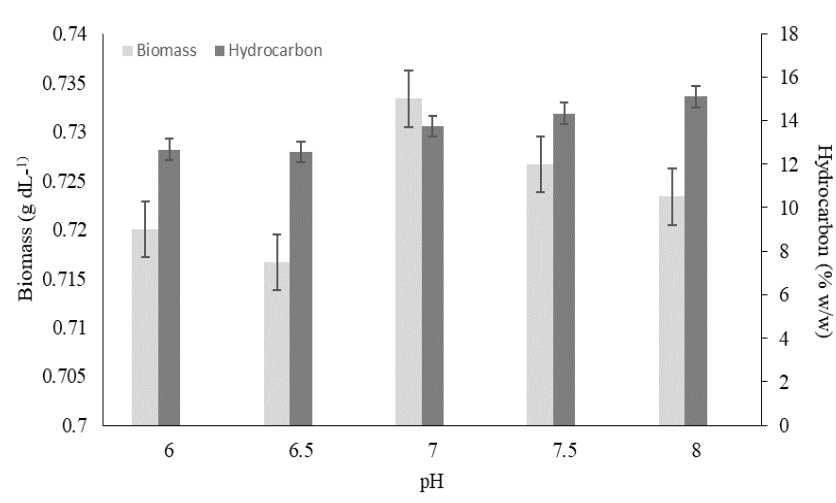

Figure 5. Effect of $\mathrm{pH}$ on biomass weight and hydrocarbon production of Botryococcus braunii 


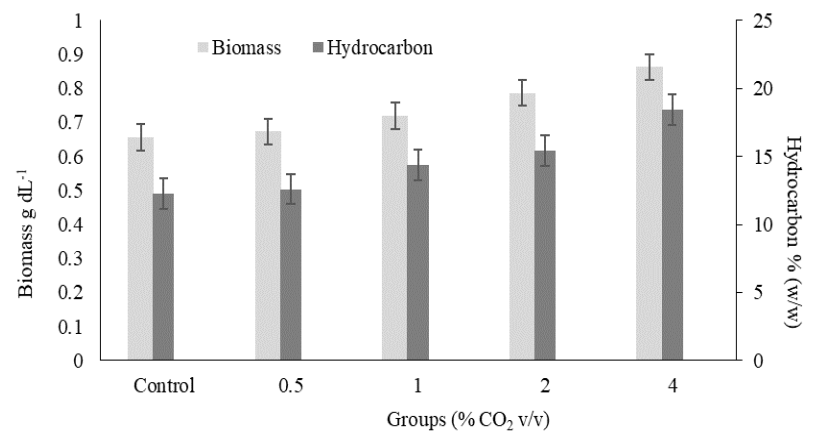

Figure 6. Effect of $\mathrm{CO}_{2}$ on biomass yields and hydrocarbon production of Botryococcus braunii

Besides $\mathrm{pH}, \mathrm{CO}_{2}$ concentration is also considered to be an important factor in $B$. braunii culture. Based on the current findings, a $4 \% \mathrm{CO}_{2}$ concentration is suitable for improving B. braunii biomass yield, hydrocarbon, chlorophyll-a, and carotenoid production (Figures 6 and 7). This finding is in agreement with previous research by Yoshimura et al. (2013), that $\mathrm{CO}_{2}$ concentration of 0.2 $5 \%$ without salinity was suitable conditions for $B$. Braunii growth. This condition is positively correlated with hydrocarbon production. Biomass dry weight of $B$. braunii was also correlated with chlorophyll-a production during cultivation; hence, chlorophyll-a is a useful parameter for monitoring B. braunii biomass growth. Hifney and AbdelBasset (2014) revealed that the addition of $5 \mathrm{mM}$ bicarbonate in combination with $6.4 \mathrm{mM}$ nitrate increased the accumulation of carotenoid in $B$. braunii, which was positively affected by successive increases in sodium bicarbonate concentrations.

To conclude, B. braunii was successfully isolated from a freshwater environment in Tenggarong, Kutai Kartanegara, East Kalimantan, Indonesia, and cultured. $B$. braunii culture has optimum growth at $\mathrm{pH} \mathrm{7-8}$ and $4 \% \mathrm{CO}_{2}$ to produce a high yield of dry biomass, hydrocarbon, chlorophyll, and carotenoid. B. braunii may also serve as a potential renewable raw material for oil or lipid production. Further research is required to evaluate the strain type and hydrocarbon composition of this particular B. braunii isolate.

\section{ACKNOWLEDGEMENTS}

The authors thank the Ministry of Research and Technology of Higher Education for the grant contract number 201/UN17.41/KL/2019, through Penelitian Dasar Unggulan Perguruan Tinggi (PDUPT), the fiscal year 2019. The authors also would like to thank Rudianto, Widha Prahastika for collecting and maintaining microalga, and all members of the Faculty of Mathematics and Natural Sciences, Mulawarman University, Samarinda, East Kalimantan, Indonesia for any kinds support.

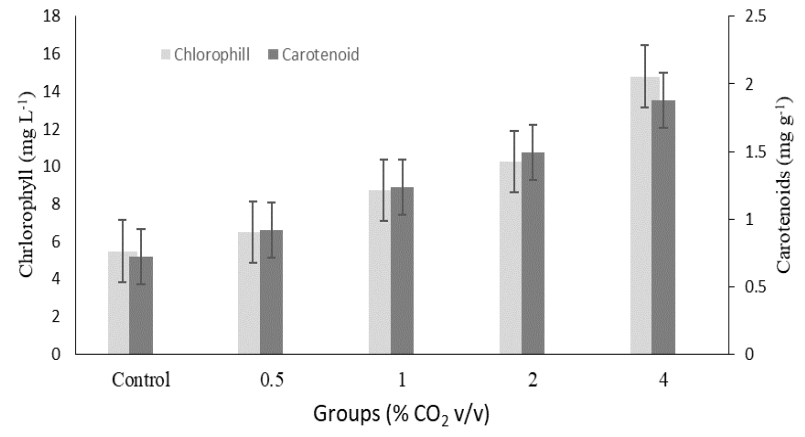

Figure 7. Effect of $\mathrm{CO}_{2}$ on chlorophyll-a and carotenoid content of Botryococcus braunii

\section{REFERENCES}

Al-Hothaly KA, Taha M, May BH, Stylianou S, Ball AS, Adetutu EM. 2016. The effect of nutrients and environmental conditions on biomass and oil production in Botryococcus braunii Race B strains. Euro J Phycol 51: 1-10. DOI: 10.1080/07388550290789513

Banerjee A, Sharma R, Chisti Y, Banerjee U. 2002. Botryococcus braunii: a renewable source of hydrocarbons and other chemicals. Crit Rev Biotechnol 22: 245-279. DOI: 10.1080/07388550290789513

Bardhan P, Gohain M, Daimary N, Kishor S, Chattopadhyay P, Gupta K, Chaliha C, Kalita E, Deka D, Mandal M. 2019. Microbial lipids from cellulolytic oleaginous fungus Penicillium citrinum PKB20 as a potential feedstock for biodiesel production. Ann Microbiol 69: 11351146. DOI: 10.1007/s13213-019-01494-3

Bertozzini E, Galluzzi L, Penna A, Magnani M. 2011. Application of the standard addition method for the absolute quantification of neutral lipids in microalgae using Nile red. J Microbiol Methods 87: 17-23. DOI: 10.1016/j.mimet.2011.06.018

Casadevall E, Dif D, Largeau C, Gudin C, Chaumont D, Desanti O. 1985. Studies on batch and continuous cultures of Botryococcus braunii hydrocarbon production in relation to physiological state, cell ultrastructure, and phosphate nutrition. Biotechnol Bioeng 27: 286295. DOI: $10.1002 /$ bit.260270312

Cepák V, Přibyl P. 2018. Light intensity and nitrogen effectively control exopolysaccharide production by the green microalga Botryococcus braunii (Trebouxiophyceae). Gen Appl Plant Physiol 8: 24-37.

Chaudry S, Bahri PA, Moheimani NR. 2018. Techno-economic analysis of milking of Botryococcus braunii for renewable hydrocarbon production. Algal Res 31: 194-203. DOI: 10.1016/j.algal.2018.02.011

Cheng P, Muylaert K, Cheng JJ, Liu H, Chen P, Addy M, Zhou C, Yan X, Ruan R. 2019. Cobalt enrichment enhances the tolerance of Botryococcus braunii to high concentration of $\mathrm{CO} 2$. Bioresour Technol: 122385. DOI: 10.1016/j.biortech.2019.122385

Concha E, Heipieper HJ, Wick LY, Navia R. 2018. Effects of limonene, n-decane and n-decanol on growth and membrane fatty acid composition of the microalga Botryococcus braunii. AMB Expr 8: 189. DOI: $10.1186 / \mathrm{s} 13568-018-0718-9$

Dayananda C, Sarada R, Bhattacharya S, Ravishankar G. 2005. Effect of media and culture conditions on growth and hydrocarbon production by Botryococcus braunii. Process Biochem 40: 3125-3131.

Dayananda C, Sarada R, Srinivas P, Shamala T, Ravishankar G. 2006. Presence of methyl branched fatty acids and saturated hydrocarbons in botryococcene producing strain of Botryococcus braunii. Acta Physiol Plant 28: 251-256.

Fiske CH, Subbarow Y. 1925. The colorimetric determination of phosphorus. J Biol Chem 66: 375-400.

Gani P, Sunar NM, Matias-Peralta HM, Latiff A, Aziz A, Kamaludin NS, Parjo UK, Emparan Q, Er CM. 2015. Experimental study for phytoremediation of Botryococcus sp. on greywater. Appl Mechan Mater 773: 1312-1317. 
Hifney AF, Abdel-Basset R. 2014. Photosynthesis, respiration and carotenoid contents in the green alga Botryococcus braunii at elevated nutrient levels. J Biol Earth Sci 4 (2): B191-B198.

Huang G-H, Chen G, Chen F. 2009. Rapid screening method for lipid production in alga based on Nile red fluorescence. Biomass Bioenerg 33: 1386-1392. DOI: 10.1016/j.biombioe.2009.05.022

Jin J, Dupré C, Legrand J, Grizeau D. 2016. Extracellular hydrocarbon and intracellular lipid accumulation are related to nutrient-sufficient conditions in $\mathrm{pH}$-controlled chemostat cultures of the microalga Botryococcus braunii SAG 30.81. Algal Res 17: 244-252. DOI: 10.1016/j.algal.2016.05.007

Johan F, Jafri M, Lim H, Maznah WW. 2014. Laboratory measurement: Chlorophyll-a concentration measurement with acetone method using spectrophotometer. IOP Conf Ser J Phys Conf Ser 1083: 012015. DOI: $10.1088 / 1742-6596 / 1083 / 1 / 012015$.

Kamalanathan M, Chaisutyakorn P, Gleadow R, Beardall J. 2018. A comparison of photoautotrophic, heterotrophic, and mixotrophic growth for biomass production by the green alga Scenedesmus sp. (Chlorophyceae). Phycologia 57: 309-317. DOI: 10.2216/17-82.1

Kimura K, Yamaoka M, Kamisaka Y. 2004. Rapid estimation of lipids in oleaginous fungi and yeasts using Nile red fluorescence. J Microbiol Methods 56: 331-338. DOI: 10.1016/j.mimet.2003.10.018

Kojima E, Zhang K. 1999. Growth and hydrocarbon production of microalga Botryococcus braunii in bubble column photobioreactors. J Biosci Bioeng 87: 811-815. DOI: 10.1016/S1389-1723(99)80158-3

Largeau C, Casadevall E, Berkaloff C, Dhamelincourt P. 1980. Sites of accumulation and composition of hydrocarbons in Botryococcus braunii. Phytochemistry 19: 1043-1051. DOI: 10.1016/00319422(80)83054-8

Lichthentaler H. 1987. Chlorophyll and carotenoids-pigments of photosynthetic biomembranes. In: Colowick SP, Kaplan NO (eds) Methods in Enzymology, Vol. 148. Academic Press, San Diego, CA.

Medipally SR, Yusoff FM, Banerjee S, Shariff M. 2015. Microalgae as sustainable renewable energy feedstock for biofuel production. BioMed Res Intl 2015: 519513. DOI: 10.1155/2015/519513.

Mercure J-F, Pollitt H, Viñuales JE, Edwards NR, Holden PB, Chewpreecha U, Salas P, Sognnaes I, Lam A, Knobloch F. 2018. Macroeconomic impact of stranded fossil fuel assets. Nat Clim Change 8: 588. DOI: 10.1038/s41558-018-0182-1

Metzger P, Largeau C. 2005. Botryococcus braunii: a rich source for hydrocarbons and related ether lipids. Appl Microbiol Biotechnol 66: 486-496. DOI: 10.1007/s00253-004-1779-z

Natunen K, Seppälä J, Koivula RJ, Pellinen J. 2017. Monitoring cell-specific neutral lipid accumulation in Phaeodactylum tricornutum (Bacillariophyceae) with Nile Red staining-a new method for Flow CAM. J Phycol 53: 396-404. DOI: 10.1111/jpy.12504. Epub 2017 Jan 25.

Nurhatika S, Ermavitalini D, Saputro TB, Apriyatmoko Y. 2018. Biodiversity and characterization of high lipid content microalgae in Porong River Estuary East Java, Indonesia. Biodiversitas 19: 577 582. DOI DOI: $10.13057 /$ biodiv/d190234

Onalo JI, Matias-Peralta HM, Mohamed Sunar N. 2014. Growth of freshwater microalga, Botryococcus sp. in heavy metal contaminated industrial wastewater. J Sci Technol 6: 29-40.

Prasertsin T, Peerapornpisal Y. 2018. Distribution and isolation of microalgae for lipid production in selected freshwater reservoirs of northern Thailand. Biodiversitas 19: 343-350. DOI: 10.13057/biodiv/d190147

Ranga Rao A, Sarada R, Ravishankar GA. 2007. Influence of CO2 on growth and hydrocarbon production in Botryococcus braunii. J Microbiol Biotechnol 17: 414-419.

Rostron KA, Rolph CE, Lawrence CL. 2015. Nile red fluorescence screening facilitating neutral lipid phenotype determination in budding yeast, Saccharomyces cerevisiae, and the fission yeast Schizosaccharomyces pombe. Antonie Van Leeuwenhoek 108: 97106. DOI: $10.1007 / \mathrm{s} 10482-015-0467-6$

Ruangsomboon S, Prachom N, Sornchai P. 2017. Enhanced growth and hydrocarbon production of Botryococcus braunii KMITL 2 by optimum carbon dioxide concentration and concentration-dependent effects on its biochemical composition and biodiesel properties. Bioresour Technol 244: 1358-1366. DOI: 10.1016/j.biortech.2017.06.042

Ruangsomboon S. 2012. Effect of light, nutrient, cultivation time and salinity on lipid production of newly isolated strain of the green microalga, Botryococcus braunii KMITL 2. Bioresour Technol 109: 261-265. DOI: 10.1016/j.biortech.2011.07.025

Sadeghin B, Sarrafzadeh M-H, Jin J, Dupre C, Watanabe M, Legrand J, Grizeau D. 2018. Variation of fatty acids composition in the hydrocarbon producer Botryococcus braunii BOT 22. Biomass Bioenergy 119: 456-461. DOI: 10.1016/j.biombioe.2018.10.013

Shuba Eyasu S, Kifle D. 2018. Microalgae to biofuels: 'Promising' alternative and renewable energy, review. Renew Sustain Energy Rev 81: 743-755. DOI: 10.1016/j.rser.2017.08.042

Storms ZJ, Cameron E, de la Hoz Siegler H, McCaffrey WC. 2014. A simple and rapid protocol for measuring neutral lipids in algal cells using fluorescence. J Vis Exp: JoVE: 51441. DOI: 10.3791/51441

Szőke-Nagy T, Hegedűs A, Baricz A, Chiriac C, Szekeres E, Coman C, Dragoș N. 2015. Identification, isolation, and bioinformatics analysis of squalene synthase-like cDNA fragments in Botryococcus terribilis AICB 870 strain. Stud Univ Babeș-Bol 60: 23-37.

Tasić MB, Pinto LFR, Klein BC, Veljković VB, Filho RM. 2016. Botryococcus braunii for biodiesel production. Renew Sustain Energy Rev 64: 260-270. DOI: 10.1016/j.rser.2016.06.009

Tripathi U, Sarada R, Ravishankar G. 2001. A culture method for microalgal forms using two-tier vessel providing carbon-dioxide environment: studies on growth and carotenoid production. World J Microbiol Biotechnol 17: 325-329. DOI: 10.1023/A: 1016682120171

Tsukahara K, Sawayama S. 2005. Liquid fuel production using microalgae. J Jpn Petrol Inst 48: 251-259. DOI: 10.1627/jpi.48.251

Tsutsumi S, Saito Y, Matsushita Y, Aoki H. 2018. Investigation of colony disruption for hydrocarbon extraction from Botryococcus braunii. Fuel Process Technol 172: 36-48. DOI: 10.1016/j.fuproc.2017.12.004

Uchida H, Sumimoto K, Oki T, Nishii I, Mizohata E, Matsunaga S, Okada S. 2018. Isolation and characterization of 4-hydroxy-3-methylbut-2enyl diphosphate reductase gene from Botryococcus braunii, race B. J Plant Res 131: 839-848. DOI: 10.1007/s10265-018-1039-4.

Uquiche E, Antilaf I, Millao S. 2016. Enhancement of pigment extraction from $B$. braunii pretreated using $\mathrm{CO}_{2}$ rapid depressurization. Braz J Microbiol 47: 497-505. DOI: 10.1016/j.bjm.2016.01.020

Wan M, Zhang Z, Wang R, Bai W, Huang J, Wang W, Shen G, Yu A, Li Y. 2019. High-yield cultivation of Botryococcus braunii for biomass and hydrocarbons. Biomass Bioenergy 131: 105399. DOI: 10.1016/j.biombioe.2019.105399

Watanabe M, Kawachi M, Hiroki M, Kasai F. 2000. Microalgae and Protozoa. Microbial Culture Collections. National Institute for Environmental Studies, Tsukuba, Japan.

Watanabe MM. 2005. Freshwater Culture. Algal culturing techniques: 13.

Xu Y, Lu A, Chen X, Su D, Wang W, Zhang Y. 2018. Isolation, identification and growth optimisation of freshwater microalgae. Turk J Fish Aquat SC 18: 1293-1302. DOI: 10.4194/1303-2712-v18_11_06

Yoshimura T, Okada S, Honda M. 2013. Culture of the hydrocarbon producing microalga Botryococcus braunii strain Showa: Optimal $\mathrm{CO}_{2}$, salinity, temperature, and irradiance conditions. Bioresour Technol 133: 232-239. DOI: 10.1016/j.biortech.2013.01.095 